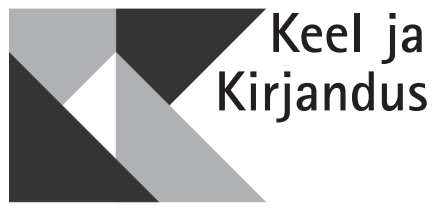

\title{
MIHHAIL PLOTNIKOV JA TEMA POEEM „JANGAL-MAA"
}

\author{
AADO LINTROP
}

\begin{abstract}
rtiklis vaatlen Mihhail Plotnikovi poeemi „Jangal-Maa”. Näitan, kuidas A see suhestub teiste vene keeles kirjutatud poeemidega, millest on hiljem 1 saanud hõimurahvaste eeposed, ja arutlen selle üle, mis motiveeris autorit niisugust teost kirjutama. Peatun pikemalt neil detailidel, mida olen leidnud autori elu kohta, esitades ka vastuolulisi kirjeldusi, ja püüan vaatlusaluse poeemi ja Plotnikovi muu loomingu põhjal selgusele jõuda autori erialases töös ning huvides. Analüüsin, kuivõrd peegeldab teos mansi folkloori ja usundit ning kas selle pidamine mansi eeposeks või rahvaluulealaseks tööks on õigustatud.
\end{abstract}

\section{Eesti keelde tõlgitud venekeelsed soome-ugri eeposed ja nende autorid}

Minu huvi soome-ugri rahvaste (kunst)eeposte vastu tekkis seoses viimastel aastatel eesti keeles ilmunud ja tõlkija poolt hõimurahvastele omistatud pikemate poeemidega, mida ühendab see, et need on kirjutanud vene autorid vene keeles. 2014. aastal jõudis eesti lugejani Mihhail Hudjakovi teos „Kõldõsini aeg. Lugulaul udmurdi vägilastest. Udmurdi eepos”, järgmisel aastal Anatoli Spiridonovi „Jugorno. Laul pühast teest. Mari eepos” ning Kallistrat Žakovi „Biarmia. Komi eepos”. 2016. aasta lõpul ilmus Mihhail Plotnikovi poeem „Jangal-Maa (Tundra). Mansi eepos”. Loetelu tekitab küsimusi. Mind 
kui folkloristi huvitab, mil määral nimetatud teosed peegeldavad udmurdi, mari, komi ja mansi rahvaluulet. Teiseks on oluline küsida, kuidas suhtuvad nimetatud rahvad ise neisse tekstidesse. Kolmandaks paneb imestama, mis põhjusel kirjutasid teise rahvuse esindajad nii mahukad poeemid just antud rahvaste pärimust silmas pidades. Neljandaks: kas neis tekstides on midagi olemuslikult ühist?

Kõigepealt mõni sõna autoritest. Mihhail Hudjakov sündis 1894. aastal vene kaupmehe perekonnas Malmõži linnas Vjatka kubermangus, õppis Kaasani ülikoolis ja tegeles Volga piirkonna rahvaste ajaloo ja arheoloogiaga. Udmurdi eepose kallal töötas Hudjakov 1920. aastail. Erinevatele uurimustele rajanev teos ei saanudki päriselt valmis, sest autor mõisteti süüdi kui aktiivne trotskistlik-zinovjevliku terroriorganisatsiooni liige ja lasti maha 19. detsembril 1936. Tekst avastati alles XX sajandi lõpul ja avaldati vene keeles 1986. aastal. Udmurdikeelne tõlge ilmus aastal 2000.

Kallistrat Žakov sündis 1866. aastal Ust-Sõssolski äärelinnas (praegu Sõktõvkar) venestunud sürjakomi peres. Ta õppis Kiievi ülikoolis, töötas kuni 1917. aasta oktoobripöördeni Peterburi psühhoneuroloogia instituudis (alates 1911. aastast professor), misjärel asus elama Tartusse ja hiljem Riiga, kus suri aastal 1926. Poeemi „Biarmia” kirjutas ta 1916. aastal. Esmakordselt ilmus see Riias Jānis Rainise lätikeelses tõlkes (1924), vene keeles sai see kättesaadavaks alles 1991. aastal ja komi keelde tõlgituna aasta hiljem.

Vene rahvusest kirjanik, tõlkija ja toimetaja Anatoli Spiridonov sündis 1950. aastal Marimaal Krasnooktjabrskis, oppis Moskvas M. Gorki nimelises kirjandusinstituudis ning töötas „Jugorno” kallal 1990. aastatel. Eepos ilmus 2002. aastal vene keeles koos marikeelse tõlkega.

Mihhail Plotnikov on nimetatud autoritest kõige salapärasem. Veel üsna hiljuti teati tema eluloost vaid seda, et ta on rahvuselt venelane, sündinud aastal $1892,{ }^{1}$ et ta on viibinud välismaal ning töötanud Siberis erinevate ajalehtede-ajakirjade toimetustes. Plotnikovi sõnul kogus ta materjali oma poeemi jaoks mansi külades ning tal võtnud aega kaksteist aastat (1915-1927), et killud omavahel tervikuks ühendada (Plotnikov 1933: 47). Poeem koos autori lühikese saatesõna ja pikema artikliga „Mansi eepika”2 ilmus 1933. aastal kirjastuselt Academia, väljaandele oli lisatud poeemi töötlus „Võidukas madur Vaza" vene luuletajalt Sergei Klõtškovilt .

Plotnikovi elukäiku ja „Jangal-Maa” tausta hakkasin lähemalt uurima pärast seda, kui Arvo Valton kutsus mind toimetama poeemi eestikeelset tõlget. Asusin tööle teadmisega, et algupärand on avaldatud vaid ühel korral. Selgus siiski, et poeem on tervikuna ilmunud ka Tjumenis sündinud vene revolutsioonilise luuletaja Sergei Knjazevi töid sisaldavas koguteoses (Knjazev, Plotnikov 1998: 357-539). Hiljem leidsin, et Tjumenis ilmuv kirjandusajakiri Lukitš avaldas aastal 2000 „Jangal-Maa” uue versiooni, mis olevat

${ }^{1}$ Novosibirski teadlaste koostatud mansi muinasjuttude ja muistendite teadusliku väljaande eessõnas märgib mansi lingvist Jevdokia Rombandejeva tema sünniaastaks 1856 (Mifõ, skazki 2005: 14).

2 „Вогульский эпос”. Ilmus esmakordselt pealkirjaga „Veneaegne mansi eepika” („Послерусский вогульский эпос”) ajakirja Sibirskije ogni 1924. aasta teises numbris. Vene keeles kasutatakse sõna эnос ka üldiselt eepika tähenduses, seega võiks artikli pealkirja siin ja edaspidi tõlkida kui „Mansi eepika”. Arvo Valton artiklit ja saatesõna poeemi eestikeelsele tõlkele ei lisanud.

${ }^{3}$ Klõtškovi poeem ilmus uuesti 2001. aastal Moskva kirjastuse Naš sovremennik väljaandel. 
autori viimase tahte väljendus (Plotnikov 2000). Väljaandele on lisatud autori 1946. aastal ümber töötatud saatesõna, mis paljuski kordab sõna-sõnalt varasemat, kuid lisab ideoloogilisi toone: „Lahkudes esivanemate teele, ei teadnud Kutonja, et mõne aasta pärast saabuvad mitte ainult mansidele, vaid kõigile Siberi põhjarahvastele helged päevad. Mansid ootasid ära oma vägimehevabastaja, kuid ta ei tulnud muusikuna taigajõe Ksenta kallastelt, vaid vene paljumiljonilise proletariaadina Lenini-Stalini partei võitmatu lipu all" (Perepletkin 2000: 17). Poeemist on vastavalt välja roogitud kõik lõigud, mis kõnelevad manside ikestamisest venelaste poolt ja Vaza missioonist mansi rahva vabastajana. Allesjäänu on üsna mõttetu action, kangelastegu kangelasteo pärast. Ehkki poeemile on lisatud üks laul, „Lenini argiš”, ${ }^{4}$ on sissejuhatusest ja 20 laulust koosnenud tekst kahanenud 14 laulu pikkuseks. Näiteks poeemi algus ja sündmustikku sissejuhatavad šamaan Kuksa kolm laulu on liidetud üheks lauluks, kus enam ei räägita venelaste poolt mansidele põhjustatud kannatustest. Alles on jäetud vaid võitlus kurja vaimu Meikiga, ehkki sedagi on muudetud. Kui poeemi esialgses versioonis põhjendatakse Meiki õelust šamaan Guzõ reeturlikkusega (vene sõjapealiku poolt ära ostetuna torkas ta vaimul silmad välja), siis uues redaktsioonis mainitakse ainult, et keegi vojevood meelitas Guzõ reetmise teele. Kõik täpsemad kirjeldused on kadunud. Puuduvad ka järgmised read:
Raskel, õnnetumal aastal
Lumemägede ent tagant
Tuli venelaste vägi
Nagu kevadvete hoovus.
Mansid läksid vibudega
Vapralt tulirelva vastu,
Kaigastega läksid mansid
Kõvast rauast püssi vastu.
(Plotnikov 2016: 13)

Mansi keelde pole Plotnikovi teost tõlgitud ühelgi kujul. Margarita Anissimkova avaldas poeemi proosatöötluse (Anissimkova 1990), mille kohta on N. Gorbatšova kirjutanud: „1990. aastal tutvustas M. Anissimkova vene lugejale oma tõlget mansi eeposest „Jangal-Maa”' (Gorbatšova 2000: 138). See näitab, et isegi Siberis tuntakse Plotnikovi poeemi nii vähe, et peetakse originaali mansi keeles kirjutatuks.

\section{Eeposed - miks ja kellele?}

Eespool nimetatud eeposte peale mõeldes kerkib mitu küsimust. Miks tuleks pidada vene kirjandusse kuuluvaid tekste soome-ugri rahvaste eeposteks? Kui marid, udmurdid ja komid ise suhtuvad neisse sel moel, ei saa meil, välistel vaatlejatel, olla midagi selle vastu. Igas kultuuris on oma tüvitekstid ja rahvuseepos tavaliselt kuulub nende hulka. Pole võib-olla esmase tähtsusega küsimus, kuidas see on saadud. Kui „Kalevipoja” oleks kirjutanud saksa kirjanik saksa keeles, aga meil oleks varsti pärast selle ilmumist läinud vaja

${ }^{4}$ Argiš - mitmel pool Siberis nimetatakse nii põdrarakendite karavani. 
rahvuslikku ärkamist turgutavat ja identiteeti loovat teost, oleksime selle ehk eesti keelde tõlkinud ja omaks võtnud. ${ }^{5}$ Seda lihtsam oli omaks kuulutada eesti keeles kirjutatud eepos, hoolimata sealsest pseudomütoloogiast. Seepärast ma ei imesta, miks vene kirjanike loomingust on saanud rahvuseeposed. Nimetatud soome-ugri eepostest kolm avaldati XX sajandi lõpul või uue sajandi esimestel aastatel - ajal, mil Nõukogude impeeriumi varemetel püüdsid uut kasvupinnast leida paljud rahvuskultuurid. Hudjakovi, Žakovi ja Plotnikovi teosed, ehkki loodud juba sajandi algupoolel, olid ühel või teisel põhjusel kohapeal täiesti tundmatuks jäänud. Spiridonovi poeem erineb neist, sest kirjutamise ja trükki pääsemise vahe oli vaid mõni aasta. Ka võis „Jugorno” autor XX sajandi viimastel aastatel toetuda hoopis teistsugustele kirjanduslikele eeskujudele ning teaduslikele uurimustele kui sajandi alguse autorid.

Kui mul tekiks tahtmine kirjutada nende rahvaste ajalugu, kombeid ja mütoloogiat puudutav värssteos, otsiksin kindlasti eeskuju rahvaluulest. Teades folkloorset tausta, tasub märkida, et udmurtidel ja maridel puuduvad eepilised ja isegi lüroeepilised laulud, komi eepilised laulud aga on suures osas sarnased vene omadega nii tegelaste kui ka süžeede poolest. Seega tuleks antud rahvaste mütoloogial põhineva pikema poeemi loomiseks otsida vormilisi eeskujusid mujalt, sisu osas aga saaks kasutada muistendite või muinasjuttude ainest. Nii ongi toiminud Hudjakov, kes lõi oma teose „Lugulaul udmurdi vägilastest” XIX sajandi lõpu ja varaste XX sajandi uurimuste ja muistendikogude põhjal, kasutades värsimõõtu (kaheksasilbiline trohheus), millel puudub vaste udmurdi folklooris. Kuid obiugrilaste (manside, hantide) rahvaluules leidub väga palju eepilisi, ka mütoloogilise sisuga laule, mis võivad moodustada pikki omavahel seotud laulutsükleid. Paraku polnud mansi poeemi autoril Plotnikovil just palju võimalusi kasutada varem kogutud materjali ja publitseeritud uurimusi. Ungari teadlaste Antal Reguly ja Bernát Munkácsi tööd polnud Siberis tõenäoliselt kättesaadavad, pealegi eeldab nende kasutamine mansi ja/või ungari keele oskust. Nagu allpool näitan, ei olnud Plotnikovi teadmised mansi keelest kuigi suured, ungari keelt ta ei osanud. Artturi Kannisto oli oma uurimisreisid alles hiljuti lõpetanud, tema materjalide avaldamiseni oli veel pikk tee. Seega polnud Plotnikovi kasutuses kuigi palju läbi töötatud materjali. Ent tema isikust rohkem teada saades olen hakanud arvama, et just üldsusele kättesaadava materjali vähesus meelitas Plotnikovi mansidest kirjutama.

Kas vene rahvusest kirjamehi motiveeris looma selliseid kirjandusteoseid huvi antud rahva ajaloo ja kultuuri vastu, süütunne, mis tekkis elades lähedases kontaktis suurvene natsionalismi poolt alla surutud rahvastega, või soov kasutada kättesaadavat ning eksootilist materjali oma kirjanduslike ambitsioonide elluviimiseks? Žakovi puhul võis mängida olulist rolli tema vanemate sürjakomi päritolu, Hudjakovi jaoks võis peamiseks teguriks olla teiste Volgaäärsete rahvaste kõrval põhjalikumalt udmurtide ajaloo ja etnograafiaga tegelemine. Plotnikovist teati veel hiljuti liiga vähe, et midagi kindlat väita, kuid uuemad andmed tema kohta aitavad neid küsimusi selgitada.

${ }^{5}$ Sama arvab ka eeposte eestindaja Arvo Valton (2015). 


\section{Mihhail Plotnikovi eluloo esimene variant: rikka reederi poeg}

Mihhail Plotnikovi kohta teavet otsides leidsin kõigepealt kirjandusteadlase Jelena Papkova artikli (2011), milles käsitletakse Plotnikovi seni ilmumata romaani „Belovodje”. Artikkel sisaldab viiteid autori elukäigule ja nappe kirjeldusi kolleegidelt ja tuttavatelt. Noor kirjanik Vsevolod Ivanov kirjutas 1917. aasta sügisel Omskist sõbrale: „Tutvusin siin [---] Mihhail Plotnikoviga. Ülemine huul alumisest lühem. Pensnee. Inglise seitel. Sinine pintsak ja püksid, pintsaku küljetaskust paistmas punase taskuräti ots. On käinud Ameerikas, Inglismaal ja Saksamaal, õppinud ülikoolis. Tark, lisaks aga suli.” (Papkova 2011) Teine kirjeldus pärineb luuletaja Sergei Markovilt, kes töötas koos Plotnikoviga Novosibirski ajalehes Sovetskaja Sibir aastatel 1925-1926: „Kõigepealt nägin ma sel ajal väga moodsat aukudega teravatipulist kaabut, seejärel kuldraamiga prille, laia, täiesti punakaslillat nägu ja sirget musta piipu... Tal oli seljas hästiõmmeldud frentš, jalas ratsapüksid, säärekaitsmed ja paksu tallaga saapad.” Markovi väitel oli Plotnikov kirju elulooga mees, kes armastas rääkida lugusid Mansimaast, kuldnaisest ja Jermaki peidetud aardest. Elukohtadena on lisaks Omskile ja Novosibirskile mainitud veel Tšitaad, Štšeglovskit (Kemerovot), Tobolskit ja Krasnojarskit, kus ta töötas peamiselt ajalehtede-ajakirjade toimetustes. Kolleegidele olevat ta rääkinud, et tema isale kuuluvad Siberi parimad aurulaevad. (Papkova 2011) Surmaajaks loetakse mitmetes töödes tinglikult aastat 1938, mil ilmus viimane Plotnikovi jutustus ajakirjas Sibirskije ogni ja mil stalinlikud repressioonid olid haripunktis. ${ }^{6}$

Nende kirjelduste ja nappide elulooliste andmete põhjal tekkis mul ettekujutus Mihhail Plotnikovist kui väga jõuka perekonna võsust, hästi ja moekalt rõivastuda armastavast maailma näinud haritud mehest, rahutu iseloomuga sageli elu- ja töökohti vahetavast seiklejast, kellele meeldis uhkustada põlisrahvaste ja peidetud aarete kohta käivate teadmistega. Poeemi ja sellele lisatud artikli põhjal oletasin, et Plotnikov liikus ka Berjozovo-Obdorski (Salehardi) piirkonnas ning puutus kokku neenetsite ja tundraeluga (sest mansidest olid poeemis saanud metsatundra ja tundra asukad). Silme ette kerkis rikas reederipoeg, kellel jätkus raha välismaareisideks, rääkimata muretust ringisõitmisest isale kuuluvate laevadega suurtel Siberi jõgedel. Mansi folkloori kogumist on Plotnikov kirjeldanud poeemi saatesõnas: „Kuude kaupa tuli suitsustes jurtades, muldonnides ja kasetohust kodades nimetute jõgede kallastel, taigas, kääbusmetsade piiril, kust algavad tundra ääretud avarused, koguda raashaaval napisõnalistelt ja umbusaldavatelt jutustajatelt lugusid vägilasest Vazast, ilusast neiust ai-Jutšost, kurjast jumalast Meikist, hirmuäratavast esivanemast Penegezest, tulilind Tauksist, Numist ja paljudest teistest „Jangal-Maa” jumalatest, kurjadest vaimudest ja kangelastest.” (Plotnikov 1933: 47)

Artiklis „Mansi eepika” mainib Plotnikov, et viibis 1920. aastal Jenissei suudmealal neenetsite juures (1933: 24). Hantõ-Mansiiski piirkonna kirjanike liidu sekretär Nikolai Konjajev märkis aga 2004. aastal Ugrimaa kirjanduselu ülevaates: „...kirjamees Mihhail Plotnikov kirjutas juba aastatel 1915-1927

${ }^{6}$ Arvo Valton kirjutas artiklis „Tõlkes leitud eeposed”, et Plotnikovile määrati 1939. aastal surmanuhtlus, kuid ta pääses sellest tänu Nikolai Ježovi arreteerimisele (Valton 2015). Kuid Ježov arreteeriti 10. aprillil 1939, Plotnikovile määrati surmanuhtlus aga alles septembris. Tjumeni kirjanike internetiandmebaas annab Plotnikovi eluaastateks 18921953. 
mansi rahvaluulet üles Berjozovos, Saranpaulis, Vanzevatis, Tegis, Šerkalõs, Kondinskojes, Samarovos ja teistes piirkonna asustatud punktides...." (Konjajev 2004). Nii kindla teadmise allikaid pole avatud.

\section{Lühidalt poeemi sisust}

Poeemi algus on esitatud šamaan Kuksa kolme lauluna, millest esimene kirjeldab mansi rahva kurba saatust. Seejärel laulab Kuksa sellest, mis on põhjustanud jumalus Meiki õeluse, laulab venelaste maaletungist, manside raskest võitlusest ning muutunud elust. Ent ta annab rahvale siiski lootust: keegi peab varastama Meiki põdrarakendi ühes luust kelguga, kihutama sellega karu Kasuk-taadi juurde ja varastama märgi, mis avab tee Torõmi valdustesse. Teel Torõmi juurde peab kangelane röövima läbipääsu valvava tulilind Tauksi sabasule. Kes sellega hakkama saab, suudab mansid vene ikkest vabastada. Noor muusik Vaza kõhkleb, kuid asub tundmatu taadi õhutusel siiski teele. Meiki valdustes kohtub ta kunagi jumaluse röövitud ilusa neiu Jutšoga, armub temasse ja vannub, et tuleb pärast ülesande täitmist tagasi. Jutšo tõotab teda karu käpa nimel oodata. Vaza jõuabki Torõmi riiki, võidab seal hiid Penegeze, pääseb kauni nõia Logari küüsist ja saab viimaks jumalalt kangelase soomusrüü ning veel kaks ülesannet: hävitada samojeede kiusav kuri merekoletis Jur ja maa-alustes valdustes elav Mammut. Ka nende ülesannetega tuleb kangelane toime. Vaza jõuab viimaks Meiki juurde tagasi ning tapab ta kahevõitluses. Jumaluse võlujõu lõppedes muutub Jutšo aga mõne hetkega raugaks ja sureb. Vaza jätab seepeale oma missiooni pooleli ning järgneb Jutšole allilma, et leida moodus ta ellu tagasi tuua. Mansid jäävad ootama tõotatud vägilast, kes tuleks ja koguks nad võitlema võõra võimu vastu.

\section{Plotnikovi uus mansi eepika}

Poeemile lisatud artiklis „Mansi eepika” kirjeldab Plotnikov uut tüüpi mansi eepikat, mille näidetena esitab katkendeid oma tollal veel pooleli olevast poeemist. ${ }^{7}$ Võrreldes uut eepikat vanaga väidab ta, et erinevalt range vormiga vanast eepikast, mis kirjeldas peamiselt mansi vürstide omavahelisi sõdu või retki hantide ja samojeedide vastu, kasutab uus eepika kõnekeelt, sel pole kindlaid vormilisi tunnuseid ja selle sisuks on mansi rahva vabastamise nimel peetav võitlus venelastega (Plotnikov 1933: 10-14). Autori sõnul räägib vana eepika „tavaliselt sõjast hantide või samojeedidega. Jutustatakse sellest, kuidas vürst läheb sõjakäiguga naabervürsti juurde ja nõuab naiseks tolle tütart" (Plotnikov 1933: 10). Uue eepika tekkimise põhjuseks peab Plotnikov manside alistamist venelaste poolt:

Pärast venelaste tulekut pole „seitsmes maailmaosas käinud ja igast neist naise saanud vägimehed-kangelased" rahvale enam olulised. Venelaste poolt alla heidetud manside mõte ja tahe keskendus rahvusliku vabastamise eest peetavale võitlusele. Kuid aastad läksid, vallutajate võim tugevnes, vabane-

${ }^{7}$ Artikkel 1933. aasta väljaandes on dateeritud aastaga 1924, lühike saatesõna aastaga 1927 (V. S.). 
mislootus üha vähenes ning rahva hingest kerkis esile uus tegelane - vägimees-lihtinimene, kes mõnikord võis pärineda ka tuntud, kuid mitte valitsenud vürstide soost; kangelane, kes pidi kangelastegusid sooritades vabastama mansid vene võimu alt. (Plotnikov 1933: 10-11)

Uut eepikat iseloomustab ta järgmiselt:

Uues eepikas puudub värvikate lausekujundite, epiteetide ja metafooride küllus; laialdaselt kasutatakse kõnekeelt, pole väljapeetust rõhkude ja vokaalide vaheldumises ning luulerütmis. Uutel bõliinadel pole rangelt lõpetatud vormi, seos erinevate episoodide vahel on tihti väga nõrk. Üks ja seesama uue eepika lugu, esitatuna eri aegadel või erinevais paigus, on raskesti äratuntav, mispärast pole sageli võimalik eri episoodidest koguda kokku terviklikku lugu. (Plotnikov 1933: 14)

Näib, et Plotnikovi uue eepika idee lähtub peamiselt kahest allikast: Serafim Patkanovi 1891. aastal ilmunud monograafiast „Handi vägimehe kuju handi bõliinades ja sangarilauludes” („Тип остяцкого богатыря по остяцким былинам и героическим сказаниям") ја Kai Donneri 1913. aastal avaldatud artiklist „A Samoyede Epic”, mille venekeelne tõlge ilmus 1915. aastal. Patkanovi tööle viidates kirjutab Plotnikov:

Rääkides uuest handi eeposest, märgib S. Patkanov, et tatari ja osalt vene valitsusajast pärinevad lood ja jutud esitatakse proosas ja sealjuures uues keeles, laenudega vanadest bõliinadest. Venelaste valitsemine lähendas enne vaenujalal olnud hõime, eri rahvaste esindajate vahelised segaabielud aitasid sellele lähenemisele veelgi kaasa, ja rahvaluule - laulud, bõliinad, tavandilaulud, šamaaniloitsud ja muu sarnane - laenati küll hantidelt mansidele, küll samojeedidelt hantidele ja vastupidi. Sama toimus ka pärismaise eepilise loominguga, mistõttu mansi eepika (mitte ainult uus) sarnaneb iseloomu ja kangelaste tüüpiliste joonte poolest paljuski handi ja isegi samojeedi omaga. (Plotnikov 1933: 14)

Muidugi on Kai Donneri analüüsitud sölkupi lood Itšast Ijast Itjast üsna sarnased mansi juttudega ekva pịriš'est, 'Eide Pojast'. Hiiglase-inimsööja Penegeze (sölkupi piirkondlikes tekstides ka Pönegesse, Pönege, Pjunekse,

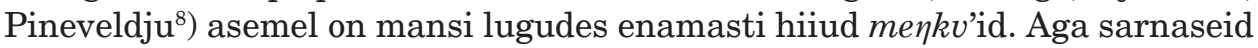
vembumehe ja rumala vanapagana lugusid leidub üle ilma, nende sarnasus ei pruugi tähendada juttude üksteiselt laenamist. Obiugri kangelaslauludes kirjeldatud lahingute puhul tuleb meeles pidada, et enamasti pole need reaalsete ajaloosündmuste peegeldused. Sõjakäigud ei toimu mitte inimeste, vaid üleloomulike olendite maailmas, kus lahinguid löövad erinevate piirkondade kaitsevaimud.

${ }^{8}$ Vt Tutškova, Wagner-Nagy 2015. 
Vaatleme lühidalt ka poeemi peategelasi. Need võib jagada kaheks: inimesed ja üleloomulikud olendid. Inimeste maailma kuuluvad poeemi peategelane Vaza ja tema armastatu Jutšo. Juba esimesel lugemisel seostasin esimese nime pardiga (mansi vas) ja leidsin selle kohta kinnituse poeemi tekstist, kus Vaza tutvustab ennast neenetsitele nii:

„Lähen sõtta Juri vastu,

Olen mansi Ksenta kaldalt,

Unustatud laulu laulja,

Sündides šamaani käest sain

Nime Vaza, tähendab see

Parti. Siia Obi maile

Tulin Torõm-isa juurest...."

(Plotnikov 2016: 75)

Jutšo nime pole sel kombel lahti mõtestatud, aga temaga seoses tuleb kindlasti nimetada Latši - meest, kes püüdis teda vägisi omaks teha, kuid kelle neiu tappis. Poeemis on olulisel kohal mansi šamaan Kuksa, kelle lauludega kogu sündmustik algab.

Üleloomulikest tegelastest tuleb kõigepealt mainida jumal Torõmit, keda autor nimetab ka Numiks ja Mirra-Susnahummiks. Tegemist on mansi taevajumala numi-tōrom'i peegeldusega (numi 'ülemine', tōram 'jumal, taevas, ilm'). Lihtsalt Num on pigem neenetsi jumalus. Mingil põhjusel on Plotnikov taevajumalaga liitnud ka Maailma Vaatava Mehe (mansi mir susne $u$ m), taevajumala ja Kaltaš-ekva poja, kes ratsutab pilvepiiril oma tiivulise hobuse seljas ja jälgib kõike maa peal toimuvat. Poeemis esinev Ortik tuleneb handi mütoloogilisest tegelasest ort iki'st (ka urt iki või urt), mis on samuti üks paljudest Maailma Vaatava Mehe nimedest.

Torõmi elupaika on poeemis kujutatud kauge kõrge taraga piiratud valdusena, kuhu viib tee läbi surnute maa. Et tegemist on taevaga, selgub alles siis, kui Vaza imestab, kuidas ta jumalate riigist nii kiiresti tagasi jõudis:

„Nõnda kiiresti ei saanud

Tagasi ma jõuda siia

Mööda riigi väravatest,

Mööda suurest tasandikust,

Elavad kus surnud hinged,

Kitsast teest, mis varjuriigis

Linnust Tauksist viib mööda.

Ma ei saanud hetkega ju

Seitsmendamast taevast alla."

(Plotnikov 2016: 70)

Obiugrilaste uskumuste kohaselt elab taevajumal tõesti taeva seitsmendal korrusel. Handi folklooris levinud vormelid näitavad, et kunagi oli taevajumal

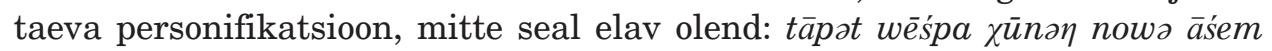
'minu seitsme harjalatiga unkaline hele (valge) isa' (Steinitz 1939: 309, 320) 


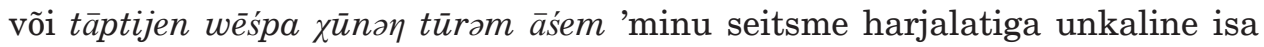
taevas' (Steinitz 1939: 355). Poeemis kujutatakse Torõmit kui panteoni valitsejat, keda ümbritsevad teised jumalad. Mansi usundist me sellist pilti ei leia, kõik jumalused elavad seal eraldi. Tõsi, mansi karupeolauludes mainitakse Torõmi poegi ja koja valvureid.

Torõmi vastasena esineb poeemis kuri jumal Meik. Üsna kindlalt võib väita, et tema loomisel kasutas Plotnikov mansi usundis ja folklooris väga levinud hiiu (mansi melkv) tegelaskuju. Tegemist pole mitte ühe olendiga, nagu kirjeldab Plotnikov, vaid üleloomulike olendite kategooriaga. Hiide on kahte

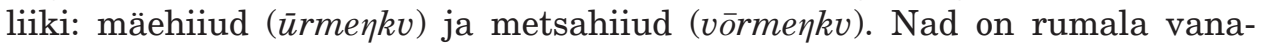
pagana sarnased suure jõu ja piiratud mõistusega tegelased, kes sageli esinevad triksterilugudes Eide Pojast. Eespool sai juba mainitud nende sugulust sölkupi Penegezega.

Väga tähtis roll on poeemis Karul, kelle suhtes kehtib sama mis hiidudegi puhul. Kuigi obiugrilased pidasid karu taevajumala maa peale laskunud lapseks, austades teda mitu päeva kestva karupeoga ning andes tema nimel vandeid, ei olnud see üks kindel müütiline karu või karude esivanem - austust väärt oli iga loom. Karu elukaaslane on poeemis Mjusne, kelles võib ära tunda mansi misne - metsaga seotud naissoost üleloomuliku olendi, küttide eksitaja. Jälle tuleb lisada, et tegemist on olendite liigiga.

Tähtsal kohal on poeemis salapärane tulilind Tauksi, kellele mansi mütoloogias vastet ei leidu. Eksisteerib küll lind kors, kes on sidepidaja maise ilma ja taevajumala vahel, kuid puudub fööniksisarnane tegelane. Kindel koht obiugrilaste mütoloogias on mammutil, keda Plotnikov nimetab kord handi sõnaga ves, kord ižmakomi sõnaga muhor 'maapõder'. Mansi sõna mā $a$ ar on viimasele üsna lähedane. Levinud uskumuse kohaselt arvati, et mammut elab maa all, kaevates seal kihvadega käike, mis mõnikord jõe kõrge kalda seest maapinnale tulevad. Seda ettekujutust aitasid toita kaldavaringutest leitud mammutiluud. Mammuti elupaika on poeemis nimetatud Petlim-jemderiks, mis näib seostuvat idapoolsete hantide kujutelmaga maa-alustest musta veega järvedest potlem-emtər, kus elas kuri vaim kul' 'allilma isand, kurat' (vt Karjalainen 1918: 348).

Merekoletis Juri pidasin algul Plotnikovi fantaasia viljaks, kuna pole sellise tegelasega obiugri tekstides kokku puutunud. Siiski leidub vastav sõna Artturi Kannisto mansi sõnastikus: jūr 'teatav veeloom, kes elab voolukeeristes; müütiline loom; veekoletis, mammut' (Kannisto jt 2014: 233). Poeemis on temast saanud küünistega vaal.

\section{Poeemis nimetatud iidolid kuldnaine ja kuldhani}

Poeemis mainitakse ka mõningaid mansi pühapaiku ja iidoleid, eelkõige nn kuldnaist, keda Plotnikov nimetab Ratšaks ning kelle pühamu asub poeemi kohaselt Berjozovo lähedal. ${ }^{9}$

Öelge nüüd, kes mäletab veel

Kuldset Ratšat, mäelt kes vette

${ }^{9}$ Lühikeses Siberi kroonikas $§ 76$ mainitakse šaitan Ratšat ja tema linna aga hoopis kusagil Belogorje lähistel asuvana. 
Esimesed teated obilaste kuldnaisest leiduvad XIV sajandi Novgorodi kroonikas viitega Permi Stefani tegevusele. XVI sajandil räägivad kuldsest iidolist Moskva suurvürsti alamad, kelle ülesandeks oli kirjeldada Venemaa laienevaid kauba- ja sõjateid. Teadaolevalt esimese eurooplasena mainib kuldset naist oma „Traktaadis kahest Sarmaatiast” Krakovi ülikooli professor Maciej Miechowita. Veel räägitakse kuldnaisest Siberi kroonikas seoses Jermak Timofejevitši retkega: Jermaki ataman Bogdan Brjazga jõudis 1582. aastal Belogorje kanti, kus nägi ugrilaste iidse naisjumaluse kuju, keda kirjeldatakse alasti koos pojaga toolil istuvana: „Sealt tuli ta Obi äärde, ja nähes asustamata paiku või hõredat asustust, peatus Belogorjes. Seal oli neil palvuspaik nende vanale jumalannale: alasti, koos pojaga toolil istuv, omadelt ohvreid vastu võttev. Ja ohverdatakse talle osa igast saagist [---] Aga kui nendeni jõudsid kuuldused Bogdani saabumisest, käskis ta ennast ära peita ja kõigil põgeneda...." (Lühike Siberi kroonika 1880: 22 (§ 79)) Madonnalaadset iidolit on kujutatud ka 1562. aastal Londonis ilmunud Anthony Jenkinsoni Venemaa kaardil. Tegelikult pole kuldnaist sellisena - üleni kullast kujuna - kindlasti olemas olnud. Teaduslikult kirjeldatud obiugrilaste pühakujude põhjal võib väita, et tõenäoliselt oli tegemist kuldehetega kaunistatud iidoliga.

Teiseks mainib Plotnikov kuldset hane Lonti (mansi lunt 'hani') lõigus, kui Torõm lubab Vazale kangelastegude sooritamise järel ihaldatud tasu: vabadust rahvastele ja endise eluviisi taastumist (Plotnikov 2016: 69-70). Ilmselt on autorini jõudnud Novitski kirjeldus XVIII sajandi algusest: „Nende poolt väga jumaldatud iidol hani on hane kujul vasest valatud, tema jõle elamu asub Belogorje külas suure Obi jõe ääres. Nende ebausu kohaselt austatakse (seal) veelindude - luikede, hanede ja muude vee peal ujuvate lindude - jumalat" (Novitski 1941: 61). Võib lisada, et hani oli obiugrilaste armastatuma jumaluse Maailma Vaatava Mehe üks esinemiskujusid. Belogorjet peetakse mõnel pool tänapäevalgi tema elupaigaks.

\section{Poeemis kasutatud „pärismaistest” sõnadest ja väljenditest}

„Maa jääb tühjaks, meie kaome

Ega uuesti siin sünni.

Kiired suusad tundra lumel

Enam siin ei libise nüüd

Rebase ja soobli jahil.

Meie kaome oma tundrast

Jõgesid ei näe me enam,

Meie haabjad on kui hauad

Mädanemas kaldaliival;

Põtradeta nartad aga

Kaovad ära rohu sisse,

Tühjaks jäänud küladesse

Pesa teevad üksnes hiired...."

(Plotnikov 2016: 10) 
Plotnikov põimib teksti hulgaliselt mansi sõnu. Ülal poeemi sissejuhatusest tsiteeritud lõigus võib sääraseid sõnu leida mitmeid: taut - tovt 'suusad',

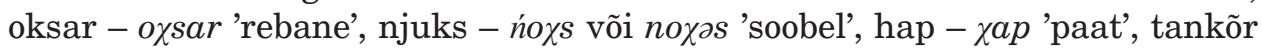
- tankar 'hiir, mutt'.

Plotnikov lisas poeemile (ja artiklile) sõnastiku, mis sisaldab 339 sõna või fraasi mitmes erinevas keeles (mansi, handi, neenetsi, sölkupi, komi, vene, tatari) (Plotnikov 1933: 595-619). Paljud mansikeelsetena välja pakutud sõnad on tegelikult handi või neenetsi päritolu, näiteks:

$a i$ 'väike, noor, tütarlaps' - handi $a j$ 'väike'; vrd mansi mań 'väike', aүi 'tütarlaps';

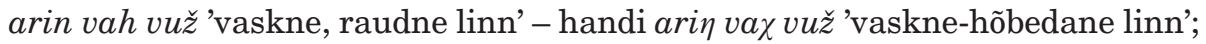
imi 'vana naine' - handi imi 'ema';

jaran-pelek 'samojeedide maa' - ilmselt handi, vrd handi päläk, pəlek 'pool, piirkond', mansi jorn 'neenets', pal 'pool';

keu 'Uurali mäed' - handi kev, mansi ńor;

lonh 'iidol' - handi lu $\chi$ 'vaim, esemetega seoses ka iidol';

madur 'kangelane' - handi matur, māDur, mansi otər;

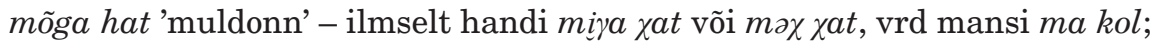

penzer 'trumm' - neenetsi penzer;

sarjata hu 'loitsija, šamaan' - handi saŕata ku, vrd mansi ńait, koipəńait

'šamaan, trummiga šamaan';

ves 'mammut' - handi ves, mansi māxar;

voi 'lind' - handi voj 'loom, lind', mansi $u j$.

\section{Plotnikovi poeem ja mansi rahvaluule}

Iseloomulik on see, kuidas Plotnikov oma poeemi abil analüüsib mansi rahvaluulet. Artiklis „Mansi eepika” kirjutab ta näiteks karu kohta:

Nagu osutavad kõik handi ja mansi muistendid, ilmus esimene karu

Kõrgel mäel, mis asub läänes,

Järsaku peal seedrisalus

Ehitas see Kasukvana

Koja, kuhu tulid need, kes

Polnud rahul saatusega,

Tulid ülekohtu ohvrid.

Tema mõistis kohut ausalt,

Süüdlased kõik mõistis surma,

Süütutega oli lahke.

(Plotnikov 1933: 22-23) $)^{10}$

Ma ei tea mitte ühtki sarnase sisuga uut ega vana obiugri teksti. Tõsi usuti, et kui karu nimel vanne anda, siis karu karistab valetajat.

Plotnikovi arusaamu obiugri folkloorist väljendavad hästi ka artikli lõigud improvisatsioonilistest lauludest:

${ }^{10}$ Värsid eestikeelses tõlkes lk 15-16, Plotnikov 2016. 
Loos märgi (tamgaa) varastamisest on kaks selgitust nõudvat kohta: Vaza improvisatsiooniline laul metsast, mis sarnaneb osalt palve või religioosse ülistuslauluga, ja Karu sõnad, millega ta Vaza poole pöördub. Karu jurta poole sõites laulab Vaza:

„Tume laas, oh laas sa vägev!

[---]

Võimas laas täis saladusi,

Laas, mu päästja ja mu hoidja,

Röövida tamgaa mul aita,

Hoia mind ka Kasuktaadi

Karuvana viha eest sa.

[---]

Palun sind ma, laas nii vägev,

Kes sa meie kodasid ja

Meie koeri, põtru hoiad,

Aita mind mu tegemistes!"

[---]

Sellised katkendid Vaza improvisatsioonilisest laulust, mis võiksid olla poeetilise improvisatsiooni musternäideteks, on põhjarahvastele üldiselt omased. Näiteks sõidab mansi metsas, näeb lund, härmatisega kaetud seedreid, oksalt oksale hüplevat väledat oravat ja juhuslikke sügavaid põdrajälgi. Kui mansil on vastav meeleolu ja kui ta üldse suudab laulda, siis ta alustab venivat laulu kõigest sellest, mida näeb.... (Plotnikov 1933: 33-34) ${ }^{11}$

Muidugi esineb mansi rahvaluules pikkade eepiliste laulude kõrval ka lüroeepikat ja improvisatsioonilisi laule. Viimaseid nimetatakse üldjuhul isiklikeks lauludeks, kuid erinevalt Plotnikovi poeemi „improvisatsioonidest” ei tegele need enamasti mitte ümbritseva looduse kirjeldamisega, vaid sellega, mida inimene teeb, tunneb ja mõtleb, ning on sageli omapärased autobiograafiad. Kuid esineb ka looduskirjeldusi, näiteks Antal Reguly kogutud ja Bernát Munkácsi abil tuntuks saanud Agapi Stepanovna Muratkova laul, milles kirjeldatakse kevadpäeva, taustaks linnujahi hääled:

Kevadaja uduse päeva lõi Torum.

Ta vaatab värske rohuga kaetud tanumalise küla tanumale:

külatanum mähkub värske rohu lahtirullitud siidi.

Ta vaatab vooremetsa poole:

vooremets rõivastub värske rohu lahtirullitud siidi.

Ta kuuleb järvekese poolt:

siidnööri pöörlemise põrisev-põrisev hääl

Isa Numi-Torumi juurde üles kandub.

Ta kuuleb jõelammi poolt:

[kus on] palju punakurk-kaure, niinenööri põrisev-põrisev hääl

Isa Numi-Torumi juurde üles kandub.

(Munkácsi 1896: 104-105 < A. Reguly)

${ }^{11}$ Värsid eestikeelses tõlkes lk 38, Plotnikov 2016. 
Tuleb rõhutada, et suur osa mansi ja ka handi rahvaluulest on olemuselt väga vormellik, olenemata sellest, kas see on üles kirjutatud XIX sajandi lõpus, XX sajandi alguses või keskpaigas. See tähendab, et üht tegelast iseloomustatakse erinevates tekstides ühtede ja samade sõnaühenditega, näiteks sooloomaküüneline, metsloomaküüneline valitseja (Püha Linna Taat), kelle linna jalp ūs (mansi) või jem voš (handi) nimetatakse alati sammuva hobuse kujuliseks, jooksva hobuse kujuliseks (handi) või sammuva hobuse laotuse kujuliseks, jooksva hobuse laotuse kujuliseks (mansi). Selliseid näiteid võib palju tuua. Vormelid on žanriülesed, esinedes nii lauludes kui ka proosajutustustes. Mõnikord, eriti karupeo repertuaaris, on handi vormelid jõudnud mansikeelsesse teksti või vastupidi. Selle võis põhjustada tõsiasi, et karupidu oli nende rahvaste ühine traditsioon ja eriti Obi-lähedastes külades võisid mansi karupeietel osaleda ka handi lauljad. Samuti olid ühised mitmed olulisemad pühapaigad, seega pole ime, kui nendega seotud vormelid ületasid keelepiire. Obiugri laule ilmestav parallelism on sageli nii absoluutne, et muudab paralleelvärsside tegelikku tähendust: näiteks ei saa handi laulu paralleelvärsse kümne hambaga hambuline suu / kahekümne hambaga hambuline suu võtta sõna-sõnalt, vaid koondtähenduses 'paljude hammastega suu'. Sageli vahetubki paralleelvärssides vaid üks sõna, näiteks viie varbaga varbalisse jalga / kuue varbaga varbalisse jalga. Vahetuvad arvsõnad viis ja kuus, kuus ja seitse, kümme ja sada. Samuti astuvad üksteise asemele sageli loom ja kala, must ja punane, siid ja kalev, vask ja hõbe, vasak ja parem, mets ja vesi jne. Leidub ka keerulisemat parallelismi, kus asendub mitu sõna. Antud juhul on oluline vaid see, et parallelism (ja ühes sellega vähesemal määral alliteratsioon) on nii mansi kui ka handi rahvaluules peamine teksti loomise printsiip, mis koos kinnisväljendite-vormelitega aitab esitajal meeles pidada ja taasluua väga pikki (sageli mitmeid tunde kestvaid) tekste. „Jangal-Maa” autoril näivad need teadmised puuduvat. Kuigi Plotnikov väidab, et uuem mansi eepika kasutab rohkelt kõnekeelt ega ehi ennast metafooride ja epiteetidega, kubiseb tema poeem poeetilistest looduskirjeldustest.

\section{Kokkuvõtvalt poeemi seostest mansi kultuuriga}

Poeemi süžee ja tegelased ei pärine otseselt mansi rahvaluulest. Olles mansi folklooriga tegelnud aastakümneid, pean nentima, et pole seni kohanud Plotnikovi mainitud uue eepika näiteid. Kuigi tekst sisaldab hulgaliselt pärismaiseid sõnu, ei ole suur osa neist mansikeelsed. Sama kinnitab Tjumeni ajaloolane Sergei Parhimovitš, kes lisaks keelelistele vigadele (Parhimoviť̌ 2002: 183) osutab ka ebatäpsustele manside olme kujutamisel. Eespool olen maininud tõika, et mansid ei asustanud tundrat ega elanud püstkodades, nagu kujutab Plotnikov. Parhimoviť̌ lisab sellised detailid nagu narid püstkojas ${ }^{12}$, mansid ringis istumas ümber tšuvali ${ }^{13}$, šamaanilaulu saateks vilepilli mängi-

12 Originaalis on narisid püstkojas nimetatud teises laulus (Jutšo kukub püstkojas narile, vt Plotnikov 2016: 16), neljandas laulus (tundmatu taat siseneb Vaza püstkotta ja istub narile; eestikeelses tõlkes on nari asemel pink, Plotnikov 2016: 25) ja kuuendas laulus (Meik magab püstkojas naril, eesti keeles on püstkoda asendatud majaga, Plotnikov 2016: 34).

13 Traditsiooniline kamina tüüpi savist tulease, paikneb maja eesnurgas. Selle ümber ei saa istuda. Eesti keelde on see tõlgitud „kogunesid kolde juurde / mansid tihedasti kokku” (Plotnikov 2016: 12). 
mine $^{14}$ jne (Parhimovitš 2002: 185). Märkasin paljusid sarnaseid seiku juba tõlget toimetades ning palusin püstkoja või tšummi asendada neutraalsema sõnaga koda, kuid mitte kõikjal pole mu soovi arvesse võetud. Nagu eelnevalt näitasin, pärinevad mansi mütoloogiast vaid mõnede poeemi tegelaste nimed, needki moonutatud kujul, olendid ise aga ei vasta mansi ettekujutustele. Šamaaniatribuutika kohta kasutatakse neenetsi sõnu. Võrreldes Kuksa šamaanilaule poeemi alguses ja neenetsi rituaali kirjeldust neljateistkümnendas laulus (Plotnikov 2016: 72-73), on asjatundjale selge, et viimase aluseks on autori reaalsed muljed, esimesed on aga puhtalt väljamõeldis. Seda kinnitab kaudselt Plotnikovi märkus artiklis „Mansi eepika”, kus ta ütleb, et kuulis 1920. aastal Jenissei-äärsete neenetsite juures kahte šamaanilaulu (Plotnikov 1933: 29). Kohtumisest mansi šamaaniga räägib Plotnikov üksnes oma poeemi lõpuridades.

Parhimovitš mainib oma artiklis, et tuntud vene ugroloog, hea mansi keele ja kultuuri tundja Valeri Tšernetsov (mansi-vene sõnastiku ning mitmete väärtuslike mansi kombestiku- ja usundialaste artiklite autor) luges Plotnikovi teost varsti pärast ilmumist ja kinnitas, et see jääb mansi rahvaluulest väga kaugele (Parhimovitš 2002: 181). Parhimovitš osutab ka, et mitmed poeemis esinevad handi sõnad pärinevad tõenäoliselt Serafim Patkanovi 1891. aastal ilmunud tööst (Parhimovitš 2002: 189) ja et Meiki nimekuju esineb Vassili Šavrovi kirjutises „Lühikesi ülestähendusi Berjozovo maakonna elanike kohta” („Краткие записки о жителях Березовского уезда”), mis ilmus 1871. aastal. Tõepoolest leiame nimetatud kirjutise kaheksandalt leheküljelt teate: „Meik, kurjuse jumal. Ta (kuju) tehakse puust ja rõivastatakse kopranahast kasukasse ja peale selle rõiva ei ehita teda millegi muuga. Metsa või steppi eksinud paluvad temalt kaitset ja eestkostet ning meelitavad teda kõiksugu ohvritega, mida ta suvatseb palujatelt vastu võtta. Sel jumalal on palju abilisi ja teenijaid...." (Šavrov 1871: 8) Šavrov mainib ka teist poeemis esinevat jumalust, Ortikut. Tulilind Tauksit peab Parhimovitš Plotnikovi enda väljamõeldiseks (2002: 185).

\section{Mihhail Plotnikovi elulugu, teine variant - zootehnikust kirjamees}

Poeemi tõlke toimetamise käigus esile kerkinud küsimused sundisid mind otsima uut informatsiooni ka autori kohta. Millal ikkagi käis Mihhail Plotnikov manside juures materjali kogumas ning kus täpsemalt ta neil reisidel viibis? Kuigi poeemi 1933. aasta väljaandele lisatud artikkel „Mansi eepika” meenutab vormilt teaduslikku uurimust, pole autor kusagil nimetanud ei materjali kogumise paiku ega informante. Tekstinäidetena esitab ta oma poeemi katkendeid, ainsaks erandiks handi isiklik laul naisevõtu teemal (Plotnikov 1933: 32).

Otsingute tulemusel leidsin kõigepealt juba mainitud Tjumeni kirjandusalmanahhi Lukitš 2000. aasta teises numbris avaldatud poeemi uue versiooni ning Juri Perepletkini artikli „Rahvarohke „Tundra”” („Многолюдная „Тундра"”), mis sisaldab ka Mihhail Plotnikovi poja Juri kirja isa elulooliste andmetega. Lisaks ilmus samas ajakirjanumbris Valeri Beloborodovi lühike kirjutis „Pseudonüümi mõistatus” („Загадка псевдонима”), mis seostab Mihhail Plotnikoviga 1928. aastal Tobolski ajalehes Sovetski Sever pseudonüümi

${ }^{14}$ Vt Plotnikov 2016: 19. 
M. Sibirjakov all ilmunud põnevusromaani „Kutšumi aare” („Клад Кучума”) (Beloborodov 2000: 8-10).

Mihhail Plotnikovi poja kirjast ei leidnud ma vastuseid kõigile mind huvitavatele küsimustele, eriti Plotnikovi elu varasemate aastate kohta. Sain teada, et „Jangal-Maa” autor ei hukkunud stalinlike repressioonide ohvrina, vaid suri alles 1953. aastal. Juri Plotnikov kirjutab isast pateetiliselt: „Mihhail Pavlovitš Plotnikovist, tema elust ja loomingust pole kerge kirjutada. Luuletaja, kirjanik, zootehnik-põhjapõdrakasvataja, ajakirjanik - selline oli Plotnikov, kes elas ränduri elu. Sahhalinist ja Kamtšatkast Põhja-Uuralini viisid teed ja rajad, mis ta läbi käis ja sõitis, ning kui lisada veel ekspeditsioonid Mongoolias, 1920. aasta retk Diksonile, osavõtt tuntud polaarlendurite esimestest pikkadest Põhjamaalendudest - kas seda kõike pole ühe inimese jaoks liiga palju?" (Perepletkin 2000: 17) Edasine otsimine viis mind materjalideni, mis annavad ühemõttelise vastuse: jah, seda kõike oli ühe inimese jaoks liiga palju.

Plotnikovi poeemi ja mõningate elulooliste andmete avaldamine aastal 2000 tekitas avalikkuses huvi tema täpsema elukäigu vastu ning Tjumeni koduloolane Aleksandr Petrušin võttis ette tee arhiividesse, et päevavalgele tuua Plotnikovi süüasi. Need materjalid avaldati sellesama ajakirja Lukitš veergudel pealkirja all „Mihhail Plotnikov: mahalaskmise toimikust”. ${ }^{15}$

Plotnikovi oma käega kirja pandud elukäigust ja ülekuulamisprotokollidest saab käesolevas artiklis vaid lühida ülevaate esitada. Neist selgub, et Mihhail Plotnikov polnud rikka reederi poeg. Ta sündis 1892. aastal Kamenka külas Novonikolajevski (praeguse Novosibirski) lähedal, tema isa Pavel Ivanovitš teenis leiba poesellina Kolõvani, Berdski ja Novonikolajevski kaupmeeste juures (Petrušin 2000a: 59). ${ }^{16}$ 1905. aastal asus Mihhail õppima Tomski reaalkooli, mille lõpetas 1912. aastal. Järgnevalt omandas ta Tomski ülikooli juures aastasel põllumajanduskursusel agronoomi erihariduse loomakasvatuse suunal (Petrušin 2000a: 56). Ja kuigi Plotnikovi haridustee sellega 1913. aasta novembris lõppes, suutis ta valeandmeid esitades piisavalt segadust luua. Nimelt kirjutas ta tööle asumisel ankeeti, et lõpetas 1913. aastal Riia põllumajandusliku polütehnilise instituudi (sic!) ${ }^{17}$ selle elulukku mahutamiseks aga nihutas kooliaastad varasemaks (1901-1908) (Petrušin 2000a: 56).

Aastatel 1914-1918 töötas Plotnikov Omski raudteel põllumajanduskonsultandina. Segastel aegadel 1918-1919 Autonoomse Siberi Ajutise Valitsuse, Ufaa Direktooriumi ja Koltšaki diktatuuri ajal oli ta ametis Kameni linnas ja Krasnojarskis. Sel ajal avaldas ta ajakirjas Sibirskije zapiski luulet, jutustusi ja ka poeemi „Jangal-Maa” esimesed seitse (teistel andmetel üheksa) laulu. ${ }^{18}$

\footnotetext{
${ }^{15}$ Kuigi toimetus väidab, et tekstid avaldati peaaegu ilma kärbete ja kommentaarideta, viitan neile edaspidi siiski lihtsuse mõttes kui Petrušini kirjutistele. Iga seal esitatud eluloolist seika ma siin eraldi ei viita, huvilised leiavad neile kinnituse Petrušini avaldatud materjalidest (Petrušin 2000a, 2000b ja 2001).

${ }^{16}$ Poja väitel sündis isa 1892. aasta novembris Obi ääres Kolõvani linnakeses tisleri peres.

${ }^{17}$ Ilmselt pidas ta silmas Riia polütehnilise instituudi põllumajandusteaduskonda. Seos nimetatud õppeasutusega seisnes Plotnikovi enese väitel selles, et ta saatis sinna oma põhjapõdrakasvatust käsitleva töö ja sai sellele positiivse vastukaja (Petrušin 2000b: 57).

${ }_{18}$ Parhimovitš väidab, et poeemi „Jangal-Maa” esimene variant ilmus samas ajakirjas juba 1916. aastal (Parhimovitš 2002: 188), Tjumeni kirjanike elektrooniline andmebaas märgib, et 1918. ja 1919. aastal ilmusid üheksa esimest laulu. Krasnojarski krai teadusliku raamatukogu andmebaasis leiduvatest ajakirja 1918. aasta digitaliseeritud numbritest leidsin seitse laulu. Esmasel lugemisel ei erine Sibirskije zapiskis ilmunud poeemi osad kuigi palju hilisemast redaktsioonist.
} 
1920. aasta suvel käis ta Krasnojarski muuseumi korraldatud ekspeditsioonil mööda Jenisseid Diksonini, mil õnnestuski tal kuulda eespool mainitud kahte neenetsi šamaanilaulu. 1921. aasta sügisel kutsuti Plotnikov Tšitaasse, kus talle pakuti tööd Kaug-Ida Vabariigi rahvusasjade ministeeriumis (pärismaalaste küsimuste spetsialistina). Plotnikov jäi Tšitaasse 1925. aasta juulini. Pärast seda jõudis ta lühikese aja jooksul töötada kuue erineva ajalehe juures. 1929. aasta septembrist 1931. aasta septembrini korraldas Plotnikov veterinaarpunkti tööd Turuhhani jõel Turuhhanski krais, seejärel aga suundus Kaug-Itta, kus leidis erialast tööd Habarovskis krai põllumajandusvalitsuses. Seal töötas ta 1937. aasta augustini põhjapõdrakasvatuse spetsialistina, misjärel oli samas linnas NSVL põllumajanduse rahvakomissariaadi palgal. 1938. aasta märtsist alates oli ta ka ajalehe Pogranitšnõi vodnik kirjanduslik kaastööline. Plotnikov arreteeriti 4. oktoobril 1938 ja mõisteti Amuuri alamjooksu jõelaevanduse sõjatribunali 1939 . aasta 10 . ja 11. septembri otsustega süüdi kontrrevolutsioonilises tegevuses, karistuseks mahalaskmine koos kogu vara konfiskeerimisega. Plotnikov kaebas otsuse edasi ja saavutas surmanuhtluse asendamise seitsmeaastase vangistusega (sama tribunali otsus 4. XI 1940), süüdistusena jäi püsima vaid fašistlike ja nõukogudevastaste seisukohtade levitamine (Petrušin 2001: 45-46, 74-75). Edasisest on teada, et väidetavalt vabanes Plotnikov 1943. aastal ning pöördus tagasi oma naise juurde Krasnojarskisse. Pärast pensionile jäämist 1947. aastal kolisid nad elama Irša asulasse Rõbinski rajooni, kus Plotnikov suri aastal 1953 (Perepletkin 2000: 18-20).

Neist andmetest nähtub, et Mihhail Plotnikov ei saanud mingil viisil kaheteistkümne aasta jooksul kuude kaupa suitsustes jurtades, muldonnides ja kasetohust kodades raashaaval mansi rahvaluulet koguda, nagu ta poeemi saatesõnas kirjeldab (Plotnikov 1933: 47). Tema tihe elulugu ei näita ühtki võimalikku „akent” Mansimaa külastamiseks. Ka ei ilmne materjalides pikki lende koos vaprate polaarlenduritega ega ekspeditsioone Mongooliasse, Kamtšatkale ja Sahhalini saarele, millest ta oli pojale jutustanud. Ülekuulamisel kinnitas ta hoopis, et töötas põllumajandusvalitsuse keskaparaadis ega puutunud kokku loomakarjadega (Petrušin 2000a: 44). Viimane väide ei vasta siiski tõele, sest hiljem rääkis Plotnikov pikemast komandeeringust evengi põhjapõdrakasvatajate juurde aastal 1935 (Petrušin 2000a: 48). Isegi kui oletada, et töö Kaug-Ida krai põllumajandusvalitsuses nõudis väljasõite kohtadele, pole tegemist poja nimetatud kangelaslike retkedega. Eluloolised andmed näitavad, et manside asemel on Plotnikov kokku puutunud neenetsite ja eriti evenkidega. Võib järeldada, et väljamõeldud kõrgharidus ja „Jangal-Maa” algusosa ilmumisega kaasnenud põlisrahvaste elu hea tundja renomee võimaldasid Plotnikovil töötada kõrgemat haridust ja isegi teaduskraadi nõudvatel ametikohtadel.

Selle põhjal, mida rääkisid temaga kokku puutunud inimesed ning mida kinnitas mingil määral ka ta poeg, võib järeldada, et Mihhail Plotnikov oli mees, kes armastas oma elu kohta väljamõeldisi levitada. 


\section{Kas šamaan Kutonja oli olemas?}

Peatun lühidalt ka Plotnikovi väitel, et tema teejuhiks mansi eepose juurde oli šamaan Kutonja. Poeemi saatesõnas kirjutab ta: „On möödunud palju aastaid, kuid ma ei suuda tänaseni unustada saja-aastase mansi küürus kuju jutustaja Kutonjat, kelle püstkoda seisis Kärbi jõe - Soss’ja ülemjooksul. [---] Meenutan alati armastuse ja tänuga Kutonjat, kes õpetas mulle mansi keelt, taati Kärbi jõelt, kes aitas mul avastada kõige salapärasemat eepost - mansi eepost „Jangal-Maa”, mis sündis ajal, kui venelased alistasid Siberi.” (Plotnikov 1933: 47-48). Tuleb mainida, et 1924. aastal ilmunud artiklis „Veneaegne mansi eepika” ja selle hilisemas redaktsioonis „Mansi eepika” (Plotnikov 1933: 9-46) ei mainita Kutonjat kordagi. Poeemi alguslaulud laseb autor esitada hoopis Kuksa-nimelisel šamaanil. Šamaan Kutonja figureerib vaid poeemi viimastes ridades.

Plotnikovi sõnul õppis ta mansi keelt just Kutonja käest, ent kuna poeemis ja artiklis kasutatud „pärismaine” sõnavara pärineb lisaks mansi murretele ka handi, neenetsi, sölkupi ja komi keelest, võib selle väite fantaasia valda liigitada. Ainus enam-vähem pädev šamaanirituaali kirjeldus leidub poeemi neljateistkümnendas laulus, kus peategelane Vaza jõuab Jamali poolsaarele, et võidelda merekoletis Juriga. Laulus esineb neenetsi šamaan, ka poeemi šamanismiga seotud sõnavara on neenetsi päritolu. Tõik sobib hästi artiklis „Mansi eepika” mainituga: „Mul õnnestus 1920. aastal Jenissei neenetsite juures Golotšika lähedal kuulata kahte šamaanilaulu, mõlemad neist püstitasid lisaks religioossetele motiividele küsimuse neenetsi rahva tuleviku kohta...." (Plotnikov 1933: 29).

Arvan, et Kutonja on tervikuna välja mõeldud andmaks poeemile veenvat raamistikku teose käsikirja valmimise järel. Autor on seda teinud nii tõepäraselt, et isegi tuntud mansi lingvist Jevdokia Rombandejeva oli veendunud tema olemasolus. Rombandejeva esitas šamaani nime mansipäraselt - Katunja - ja märkis, et see tähendab tõlkes 'kätt omav', s.o 'raviva käega' (Mifõ, skazki 2005: 14). Tõesti on 'käsi' mansi keeles kat, 'kätt omav' võiks olla siis kat ońśi,$^{19}$ aga kuidas saab Plotnikovi Kutonjast Rombandejeval Katunja?

Võimalik, et Kutonja näol on tegemist Henry Wadsworth Longfellow eepose mõjuga. Udmurdi folklorist Vladimir Napolskihh on oletanud, et Hudjakovi poeemi „Lugulaul udmurdi vägilastest” eeskujuks pole mitte niivõrd „Kalevala” kui „Laul Haiavatast”. On tähelepanuväärne, et kuigi eeposed ilmusid vene keeles kõigepealt kümneaastase vahega - „Kalevala” Leonid Belski tõlkes 1888, „Laul Haiavatast” Ivan Bunini tõlkes 1898 -, said mõlemad tõlked Puškini auhinna ja publitseeriti seejärel uuesti kõigest aastase vahega (1915 ja 1916) tuntud Moskva kirjastuses M. ja S. Sabašnikov. Napolskihh analüüsib: „Vaatame kõigepealt poeemi autori üldist positsiooni: K[alevalas] räägib autor oma rahva nimel ja selle rahva keeles, H[aiavatas] ja L[ugulaulus] $\mathrm{u}$ [dmurdi] v[ägilastest] jutustab autor omas keeles (inglise, vene) ümber teise rahva (odžibved, udmurdid) muistendeid, nimetades neid rahvaid nimepidi ja kasutades ainult mõnda pärismaise keele sõna (rahvanimed, kangelaste nimed jne). [---] Autori positsioonist lähtub loo päritolu ja allikas, mida tutvustatakse sissejuhatavas laulus: K[alevalas] ütleb autor, et kuulis neid laule vanematelt ja „kogus” neid kogu eluaja oma kodumaa looduses, H[aiavatas] ja

${ }^{19}$ Mansi folklooris on eelistatum omadussõnaline vorm katəๆ 'käeline'. 
L[ugulaulus] u[dmurdi] v[ägilastest] ütleb autor, et kuulis neid laule (või kogu poeemi) pärismaiselt laulikult, keda ta teab nimepidi (Nawadaha, Ožmeg)." (Napolskihh 2003: 281-282)

Lisaksin siia ritta ka Plotnikovi poeemi. Võrrelgem:

I repeat them as I heard them

From the lips of Nawadaha, The musician, the sweet singer.

(Longfellow 1855: 4)

Kuulsime neid laule meie

Saja-aastaselt Ožmegilt,

Suur-Dokja kes külast pärit,

Halli karu suguvõsast.

(Hudjakov 2014: 13)

Aga mansid vanataati,

Kalurit siin Sosva jõesuus

Teavad mitte kui Petruškat

Vaid kui Lutsutrummi või ka

Parem kui šamaan Kutonjat.

Siis, kui teelisel on soovi,

Jutustab ta öisel ajal

Sellest, mis on kirja pandud

Siia raamatusse, mille

Olen nimetanud „Tundraks”-

„Jangal-Maa” see mansi keeles.

(Plotnikov 2016: 113)

Nagu Hudjakovi Ožmeg oli Plotnikovi Kutonjagi saja-aastane. Longfellow laulik Nawadahaga sarnaselt oli ka Plotnikovi muusik Vaza imekaunis.

\section{Kokkuvõtteks}

Esitatud Mihhail Plotnikovi biograafia näitab, et eepose loomiseks ei saanud ta pikki aastaid tegeleda mansi folkloori kogumisega. Aeg põllumajanduskursuse lõpetamise ja poeemi esimeste laulude ilmumise vahel on kõigest veidi üle nelja aasta. Kõik need aastad töötas Plotnikov Omski raudteel. Lisaks poeemile kirjutas ta neil aastatel lüürikat ja avaldas Sibirskije zapiskis kaks jutustust: 1916. aastal „Jumala põhjapõdrad” ning 1918. aastal „Põhjapõdrakünkal”. Mõlema tegevus toimub mansi külas ja mõlemad sisaldavad mansikeelseid sõnu-väljendeid. Samuti leiame esimesest kõrvaltegelasena šamaan Guzõ, teisest aga šamaan Kuksa (Plotnikov 1916, 1918).

Mansi folkloori tundja ja uurijana võin kinnitada, et „Jangal-Maa” seostub eheda mansi folklooriga veidi suuremal määral kui Karl August Hermanni lauleldus „Uku ja Vanemuine” eesti rahvaluulega. Kui poleks teadusliku artiklina välja pakutud kirjutist „Mansi eepika”, poleks mul Plotnikovile ühtki 
etteheidet. Iga autor on vaba looma just sellist teost, nagu soovib, ja nimetama seda ükskõik milleks. Poeemile lisatud artikkel aga juhatab lugeja sihilikult valedele jälgedele.

Võin pakkuda kahte oletuslikku seletust, miks paelusid mansid Plotnikovi. Esimene seostub kirjaniku seiklejanatuuriga ja huviga kõige mõistatusliku vastu, mille äratasid kuuldud lood Kutšumi peidetud varandusest või obiugrilaste kuldsetest jumalakujudest. Seda oletust kinnitavad nii tema ajakirjanikest kolleegide vihjed kui ka Plotnikovi muu looming, mis reedab huvitumist just sarnastest salapäraga varjutatud asjadest: näiteks romaan „Kutšumi aare” või seni ilmumata jutustus „Belovodje”, mille loomisel on kasutatud vene folklooris levinud müütilise õiglaste ja usklike (tõotatud) maa motiive. Teine seletus seostub Plotnikovi oblastniku vaadetega, ${ }^{20}$ selle Siberi autonoomiat eesmärgiks seadva liikumise häälekandjaks oli mingil määral ka ajakiri Sibirskije zapiski. Plotnikovi varaste jutustuste ideaaliks on siberlaste, olgu need mis tahes rahvusest, sõbralik ja üksteisele kasulik kooseksisteerimine ja vastupanu suurvene mõjudele. Ehk leidis ta just sellest ideoloogiast lähtuvalt mansid - väikerahva, kes Siberis esimesena vene vallutajatega kokku puutus. Ka jutustus „Linnus Kava ääres” seostub nende sündmustega (Plotnikov 1938).

Tõenäoliselt jääbki saladuseks, kust omandas Mihhail Plotnikov lisaks eespool mainitud Kai Donneri ja Sergei Patkanovi teostele oma napid teadmised mansi keele ja folkloori kohta. Võib-olla oli tal Tomskis õppides mõni mansi päritolu sõber, võib-olla puutus ta mansidega kokku Omski raudteel töötades. Igatahes peavad need teadmiskillud pärinema ajast enne poeemi esimeste laulude ilmumist.

Analüüsides poeemi vormilisi ja sisulisi aspekte, kasutatud pärismaist sõnavara ja seoseid mansi mütoloogiaga, jõudsin järeldusele, et kuigi „Jangal-Maa” sisaldab mõningaid mansi pärimusega seostuvaid detaile, on see tervikuna siiski Plotnikovi looming ja lähtub autori soovist luua kirjandusteos, mis võiks vene kultuuriruumis paigutuda samasse kategooriasse Henry Wadsworth Longfellow' „Laul Haiavatast” tõlkega. Seega pole õige käsitleda „Jangal-Maad" kui folkloristlikku tööd ega pidada selle autorit rahvaluuleteadlaseks. Mihhail Plotnikovi ambitsioon oli selgelt kirjanduslik ja sellest peaksime tema teost analüüsides lähtuma.

Artikli valmimist on toetanud Euroopa Liit Euroopa Regionaalarengu Fondi kaudu (Eesti-uuringute Tippkeskus), see on seotud Eesti Haridus-ja Teadusministeeriumi uurimisprojektiga „Folkloor kultuurilise kommunikatsiooni protsessis: ideoloogiad ja kogukonnad" (IUT 22-4).

${ }^{20}$ Oma vaateid aastatel 1914-1919 selgitab Plotnikov põhjalikult kohtuasjale liidetud omakäelistes tunnistustes. Hiljem kohtu ees ütles ta antud tunnistuste kohta, et kuna ta kartis ülekuulamistel füüsilist mõjutamist, sisaldavad need ka valet, kuid on suuremas osas siiski tõesed (Petrušin 2001: 39). Kirjas sõjaväeprokurörile (15. VII 1940) palub ta arvestada, et omakäeline tunnistus on kirjutatud surve all pääsemaks uurija Kaskevitši piinamisest (Petrušin 2001: 61). Siiski on lugejal kerge vahet teha vägivalla mõjul üles tunnistatud nõukogudevastasesse salaseltsi kuulumisel ja rahulikel maailmavaatelistel aruteludel. 


\section{Võrguviited}

Плотников, Михаил Павлович. - Электронная библиотека тюменского писателя http://writer-tyumen.ru/index.php?m=autor\&aid=77 (20. IV 2017)

\section{Kirjandus}

A n i s s i m k ov a 1990 = Маргарита Кузьминична Анисимкова, Янгал-Маа (Тундра): вольная обработка в прозе мансийского поэтического эпоса. Москва: Столица.

B el o b o r o d ov 2000 = Валерий Константинович Белобородов, Загадка псевдонима. - Лукич, kd 12, nr 2, lk 8-10.

Donner, Kai 1913. A Samoyede Epic. - Journal de la Société Finno-Ougrienne 1913-1918, nr 30, lk 1-13.

D o n n e r 1915 = Кай Доннер, Самоедский эпос. Труды томского общества изучения Сибири, kd 3, v 1. Томск, lk 38-53.

Gorbatš ov a $2000=$ Н. Н. Горбачева, Заметки о прозе М. Анисимковой. - Космос Севера, v 2. Екатеринбург, lk 137-143.

H u dj a k ov, Mihhail 2014. Kõldõsini aeg. Lugulaul udmurdi vägilastest. Udmurdi eepos. Tlk Arvo Valton, toim Muš Nadii. Tallinn: Kirjastuskeskus.

Kannisto jt 2014 = Wogulisches Wörterbuch. (Lexica Societatis Fenno-Ugricae XXXV. Kotimaisten Kielten Keskuksen Julkaisuja 173.) Kogunud Artturi Kannisto, koost Vuokko Eiras, toim Arto Moiso. Helsinki: Société Finno-Ougrienne, Kotimaisten Kielten Keskus, 2014.

Karjalainen, Kustaa Fredrik 1918. Jugralaisten uskonto. (Suomensuvun uskonnot III.) Porvoo: WSOY.

Knjazev, Plotnikov 1998 = Василий Васильевич Князев, Михаил Павлович Плотников, Русь: Избранное. (Невидимые времена 9.) Тюмень: Софтдизайн.

Konj aj ev 2004 = Николай Иванович Коняев, Вчера, сегодня и всегда: ретровзгляд на литературную жизнь Югры. - Писатели Югры. Екатеринбург: Сократ, lk 3-33. http://hmao.kaisa.ru/file/1809553118?lc=ru (20. IV 2017)

Longfellow, Henry Wadsworth 1855. The Song of Hiawatha. London: David Bogue.

Lühike Siberi kroonika 1880 = Краткая Сибирская летопись (Кунгурская). С.-Петербург.

Mifõ, skazki 2005 = Мифы, сказки, предания манси (вогулов): в записях 1889, 1952, 1958-1960, 1968, 1978, 1992, 2002 годов. (Памятники фольклора народов Сибири и Дальнего Востока 26.) Ред. Евдокия Ромбандеева. Москва-Новосибирск: Наука.

M u n ká c si, Bernát 1892. Vogul népköltési gyưjtemény II, 1. Istenek hôsi énekei, regéi és idézố igéi. Budapest: Franklin Ny.

Munkácsi, Bernát 1896. Vogul népköltési gyứjtemény IV, 1. Életképek. Sorsénekek, vitézi énekek, medveünnepi szinjátékok, állaténekek, mesék, találós mesék, néprajzi apróságok, földrajzi névjegyzék. Budapest: Franklin Ny.

Napolskihh 2003 = Vladimir Napolskikh, On the literary sources of M. G. Khudiakov's „Song of Udmurt Heroes”. - Dynamics of Tradition. Perspectives on Oral Poetry and Folk Belief. (Studia Fennica Folkloristica 13.) Toim Lotte Tarkka. Helsinki: Finnish Literature Society, lk 280-288.

Novitski 1941 = Григорий Ильич Новицкий, Краткое описание о народе остяцком сочиненное Григорием Новицким в 1715 году. Новосибирск: Новосибгиз. 
Papkova 2011 = Елена Папкова, „Беловодье” Михаила Плотникова: русская литература 1-й трети XX в. в поисках крестьянского рая. - Сибирские огни, nr 4. http://www.sibogni.ru/content/belovode-mihaila-plotnikova-russkaya-literatura-1-y-treti-xx-v-v-poiskah-krestyanskogo-raya (20. IV 2017).

Parh im ovitš 2002 = Сергей Григорьевич Пархимович, „Янгал-маa”: много шума из ничего. - Лукич, $\mathrm{kd} \mathrm{22,} \mathrm{nr} \mathrm{2,} \mathrm{lk} \mathrm{180-189.}$

Patkanov 1891 = Серафим Патканов, Тип остяцкаго богатыря по остяцким былинам и героическим сказаниям. С.-Петербург.

Perepletkin 2000 = Юрий Иванович Переплеткин, Многолюдная „Тундра”. Лукич, kd 12, nr 2, lk 11-20.

Petru š in 2000a = Александр Петрушин, Михаил Плотников: Из дела о расстреле. - Лукич, kd 15, nr 5, lk 42-85.

Petru š in 2000b = Александр Петрушин, Михаил Плотников: Из дела о расстреле. - Лукич, kd 16, nr 6, lk 56-89.

Petruš in 2001 = Александр Петрушин, Михаил Плотников: Из дела о расстреле. - Лукич, kd 17, nr 1, lk 36-76.

Plotnikov 1916 = Михаил Плотников, Божьи олени. - Сибирские записки, $\mathrm{nr} 4$, lk 2-16.

Plotnikov 1918 = Михаил Плотников, На оленьем холме. - Сибирские записки, nr 1, lk 3-21; nr 2-3, lk 2-19.

Plotn i k ov 1924 = Михаил Плотников, Послерусский вогульский эпос. - Сибирские огни, nr 2, lk 124-159.

Plotnikov 1933 = Михаил Плотников, Янгал-маа. Вогульская поэма со статьей автора о вогульском эпосе. Сергей Клычков, Мадур Ваза победитель. Вольная обработка поэмы „Янгал-маа”. Москва-Ленинград: Academia.

Plotnikov 1938 = Михаил Плотников, Городок на Каве. - Сибирские огни, nr 2, lk 70-100.

Plotnikov 2000 = Михаил Плотников, Янгал-маа (Тундра). Поэма. - Лукич, kd 12 , nr 2, lk 21-43.

Plotnikov, Mihhail 2016. Jangal-Maa (Tundra). Mansi eepos. Tlk Arvo Valton, toim Aado Lintrop. Tallinn: Kirjastuskeskus.

Sok olov a 1983 = Зоя Петровна Соколова, Социальная организация хантов и манси в XVIII-XIX вв. Проблемы фратрии и рода. Москва: Наука.

S pir i d on ov, Anatoli 2015. Jugorno. Laul pühast teest. Mari eepos. Tlk Arvo Valton, toim Muš Nadii. Tallinn: Kirjastuskeskus.

Steinitz, Wolfgang 1939. Ostjakische Volksdichtung und Erzählungen aus Zwei Dialekten. 1. Teil. Grammatische Einleitungen und Texte mit Übersetzungen. (Õpetatud Eesti Seltsi Toimetused XXXI.) Tartu: K. Mattiesen.

Šavrov 1871 = Василий Николаевич Шавров, Краткие записки о жителях Березовского уезда. Москва: Общество во истории и древностей российских при Московском университете.

Ža k ov, Kallistrat 2015. Biarmia. Komi eepos. Tlk Arvo Valton, toim Nikolai Kuznetsov. Tallinn: Kirjastuskeskus.

Tutškova, W a g n e r - N a g y 2015 = Наталья Тучкова, Беата Вагнер-Надь, „Семи богов мудростью обладающий Итте...” Тексты с героем Итя в селькупском фольклоре. Часть 1. Итя-тексты. Томск.

V alt o n, Arvo 2015. Tõlkes leitud eeposed. - Sirp 11. XII.

Vogul Folklore 1995 = Vogul Folklore Collected by Bernát Munkácsi. (ISTOR books

4.) Toim Otto J. von Sadovszky, Mihály Hoppál. Budapest: Akadémiai Kiadó; Los Angeles: International Society for Trans-Oceanic Research. 
Keywords: Mansi epic, Mansi folklore, Ob-Ugrian folklore, Mikhail Plotnikov

The poem Yangal-Maa was written in Russian by Mikhail Plotnikov and published in its entirety in 1933. Its Estonian translation (2016) is subtitled as „Mansi epic”. The research questions asked in the article are: What prompted the author to write such a piece? How well did he know Mansi folklore and to what extent does the poem reflect it? The introduction also provides a short overview of some other epics of the kindred Finno-Ugric peoples, which have been written in Russian and translated into Estonian. Considering the plot, setting, characters and the „indigenous” lexis embedded in the text we can conclude that although there are some characters originating in Mansi folklore, their names are presented in a distorted form (cf. the Mirra-Susnahumm and Meik of the poem and the respective Mansi mir susne $\chi u m$ and mejkv) and their nature is mostly very far from their folkloric or religious origins. The forest giant menkv, for example, has been given the role of the adversary of the heavenly god instead of the Ob-Ugrian devil, who is called kul'. Although heroic songs make up a large share of Mansi folklore, there is not one authentic song describing the hero's fight for the liberation of the Mansi people. As for everyday life, living in conical huts is not Plotnikov's only error. At the beginning of the $20^{\text {th }}$ century the typical Mansi dwelling was a small rectangular log house, while the conical hut was called a Nenets house (jorn $\mathrm{kol}$ ). Many of the alleged Mansi words and expressions embellishing the text actually represent either the Khanty, Nenets, Selkup or Izhma-Komi language, while the Mansi words often occur in a distorted form. The metre of the poem is trochaic tetrameter, which, despite being characteristic of other Finno-Ugric epics, is alien to Mansi folklore. Nor has the author of the poem used the devices typical of Ob-Ugrian folklore, such as parallelism, alliteration, or formulaic language. Although an author is entitled to write any fiction, the presentation of one's own fantasy as authentic folklore, as is done in Plotnikov's article „Mansi epics” supplemented to the poem, surpasses the limits of creative freedom. Notably, according to the article Plotnikov had collected the material for the poem bit by bit, during his visits to Mansi villages over twelve years, but an analysis of his biography denies a possibility of his staying at Mansi villages, even for a short while.

Aado Lintrop (b. 1956), PhD, Estonian Literary Museum, Senior Researcher, aado@folklore.ee 